\title{
Sangiangols A and B, Two New Dolabellanes from an Indonesian Marine Soft Coral, Anthelia sp.
}

\author{
Novriyandi Hanif ${ }^{1, *(\mathbb{D}}$, Anggia Murni ${ }^{2}$ and Junichi Tanaka ${ }^{3}$ (I) \\ 1 Department of Chemistry, Faculty of Mathematics and Natural Sciences, IPB University, \\ Bogor 16680, Indonesia \\ 2 Tropical Biopharmaca Research Center, IPB University, Bogor 16128, Indonesia; \\ anggia_murni@apps.ipb.ac.id \\ 3 Department of Chemistry, Biology and Marine Science, University of the Ryukyus, Nishihara, \\ Okinawa 903-0213, Japan; jtanaka@sci.u-ryukyu.ac.jp \\ * Correspondence: nhanif@apps.ipb.ac.id; Tel.: +62-251-862-4567
}

Academic Editor: Vassilios Roussis

Received: 20 July 2020; Accepted: 18 August 2020; Published: 21 August 2020

check for updates

\begin{abstract}
A new, rare trinor-dolabellane diterpenoid, sangiangol A (1), and one new dolabellane diterpenoid, sangiangol B (2), together with known cembranes and dolabellanes (3-8), were isolated from the ethyl acetate layer of an extract of an Indonesian marine soft coral, Anthelia sp. Compounds 1-8 exhibited moderate cytotoxicity against an NBT-T2 cell line $(0.5-10 \mu \mathrm{g} / \mathrm{mL})$. The structures of the new compounds were determined by analyzing their spectra and a molecular modelling study. A possible biosynthetic pathway for sangiangols A (1) and B (2) is presented. Cytotoxicity requires two epoxide rings or a chlorine atom, as in 4 (stolonidiol) and 5 (clavinflol B).
\end{abstract}

Keywords: soft coral; dolabellane; cytotoxicity; NMR; molecular modelling

\section{Introduction}

Soft corals produce numerous, structurally diverse, biologically active terpenoids [1]. More specifically, Indonesian alcyonaceans are rich sources of diterpenoids with a variety of molecular skeletons. From 1970-2017, eight diterpenoid skeletons (briarane, cladiellane, seco-cladiellane, cembrane, nor-cembrane, dolabellane, flexibilane, and xenicane) were discovered in 11 genera of Indonesian alcyonaceans [2]. Among them, cembrane and briarane skeletons comprise a majority of the known diterpenoids in soft corals globally [2,3]. To date, soft corals of the genus Anthelia, family Xeniidae, have been shown to contain one type of sesquiterpenoid [4], three types of diterpenoids (xenicane [5], dolabellane [6], a $\mathrm{C}_{24}$-acetoacetylated diterpenoid [7,8]), and one type of steroid [9] with cytotoxic activity against various cell lines [4-9]. Moreover, the dolabellane stolonidiol (4), was identified as a promising candidate against Alzheimer's disease after its mode of action in HEK293 cells was determined [10]. In our continuing study of metabolites of Indonesian Anthelia [4,6], we isolated known diterpenoids 3-8 and new dolabellanes, named sangiangols A (1) and B (2), the structures of which are the subject of this article.

\section{Results and Discussion}

A sample of the soft coral Anthelia sp., collected at Banten (BTN) in northwestern Java, was thoroughly extracted with acetone. After concentration, the residue was partitioned between EtOAc and $\mathrm{H}_{2} \mathrm{O}$. The EtOAc extract showed significant cytotoxicity against NBT-T2 cells at $1 \mu \mathrm{g} / \mathrm{mL}$. Thus, it was chromatographed on silica gel, followed by normal or reversed phase HPLC to afford two new molecules, $\mathbf{1}$ and $\mathbf{2}$, along with known compounds 3-8 (Figure 1). 

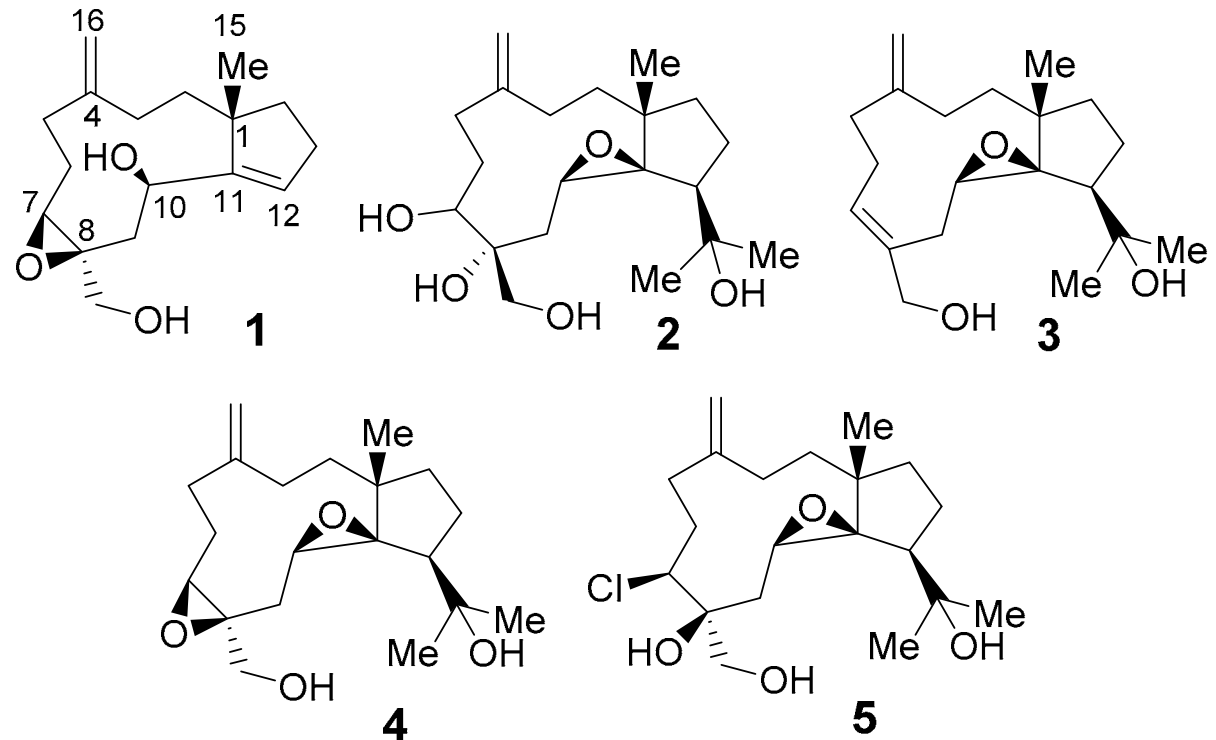

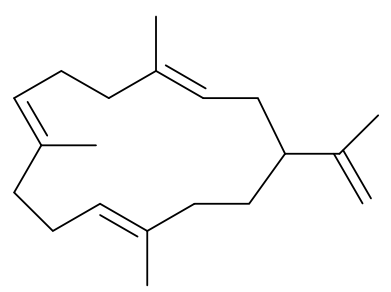

6

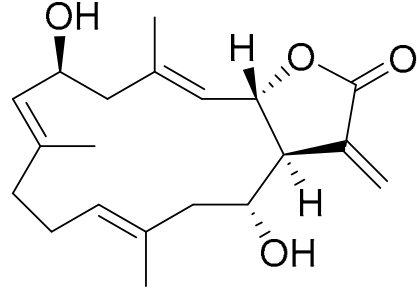

7

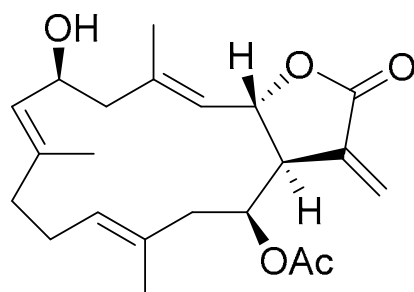

8

Figure 1. Chemical structures of dolabellane-type molecules (1-5) and cembrane-type molecules (6-8).

Sangiangol A (1) was obtained as an optically active oil, $[\alpha]_{D}{ }^{27}+20$. Its molecular formula is $\mathrm{C}_{17} \mathrm{H}_{26} \mathrm{O}_{3}$ by HRESIMS and NMR (Table 1 ), indicating five degrees of unsaturation. Two compounds were identified as olefins $\left(\delta_{\mathrm{C}} 153.0(\mathrm{C}) ; 127.0(\mathrm{CH})\left(\delta_{\mathrm{H}} 5.88 \mathrm{brt}, J=2.5\right) ; 150.1(\mathrm{C}) ; 111.4\left(\mathrm{CH}_{2}\right)\left(\delta_{\mathrm{H}} 4.70 \mathrm{~s}\right.\right.$, $4.76 \mathrm{~s}))$ and three others were assigned to a trisubstituted epoxide $\left(\delta_{\mathrm{C}} 61.3(\mathrm{CH})\left(\delta_{\mathrm{H}} 3.06 \mathrm{t}, J=6.5\right)\right.$; $\left.\delta_{\mathrm{C}} 63.7(\mathrm{C})\right)$ and a bicyclic structure. IR absorption at $3310 \mathrm{~cm}^{-1}$ and at 1714 and $1040 \mathrm{~cm}^{-1}$ suggested the presence of hydroxy and exomethylene groups, respectively.

Four spin systems $\mathbf{i}-\mathbf{i v}\left(\mathbf{1 a}\right.$; Figure 2 ) were disclosed by inspecting ${ }^{1} \mathrm{H}-{ }^{1} \mathrm{H}$ COSY cross peaks: (i) a trisubstituted double bond next to two methylenes $\left(\delta_{\mathrm{H}} 5.88,2.31,2.10,1.84,1.63 ; \mathrm{H}-12\right.$ to H-14), (ii) an oxymethine connected to a methylene $\left(\delta_{\mathrm{H}} 2.20,4.40 ; \mathrm{H}-9\right.$ to $\left.\mathrm{H}-10\right)$, (iii) the epoxide methine next to two methylenes $\left(\delta_{\mathrm{H}} 2.42,2.22,1.73,3.06 ; \mathrm{H}-5\right.$ to $\left.\mathrm{H}-7\right)$, and (iv) two methylenes $\left(\delta_{\mathrm{H}} 1.63,1.50,2.10\right.$, 1.73; H-2 to H-3). A small coupling $\left({ }^{4} J_{\mathrm{H}-\mathrm{H}} 1.3 \mathrm{~Hz}\right)$ between $\mathrm{H}-10$ and $\mathrm{H}-12$ with a COSY cross peak supported the presence of an allylic alcohol in Figure 2 (1a). HMBC correlations for H-10/C-8, 9, 11, 12 and $\mathrm{H}-12 / \mathrm{C}-1,10,11,13,14$ confirmed the connection of spin systems $\mathbf{i}$ and ii. The trisubstituted epoxide was placed at $\mathrm{C}-7$ and $\mathrm{C}-8$, connecting spin systems $\mathrm{ii}$, iii, and a primary alcohol $\left(\delta_{\mathrm{H}} 3.38\right.$, 4.07) by observing HMBC correlations for H-7/C-6, 17; H-10/C-8; H-9/C-7, 8, 17; H-17a,b/C-7, 8, 9. Spin systems iii and iv were connected through an exomethylene $\left(\delta_{\mathrm{H}} 4.70 \mathrm{~s}, 4.76 \mathrm{~s} ; \delta_{\mathrm{C}} 153.0,111.4\right)$ placed at $\mathrm{C}-4$, as HMBC correlations $\mathrm{H}-16 \mathrm{a}, \mathrm{b} / \mathrm{C}-3,4,5$ were observed. Finally, correlations from $\mathrm{H}_{3}-15$ to $\mathrm{C}-1$, $2,11,14$ supported the connection of spin systems $\mathbf{i}$ and $\mathbf{i v}$, confirming the planar structure of $\mathbf{1}$ as a trinor-dolabellane diterpenoid. 
Table 1. ${ }^{1} \mathrm{H}$ NMR data for compounds 1 and 2 in $\mathrm{CDCl}_{3}$.

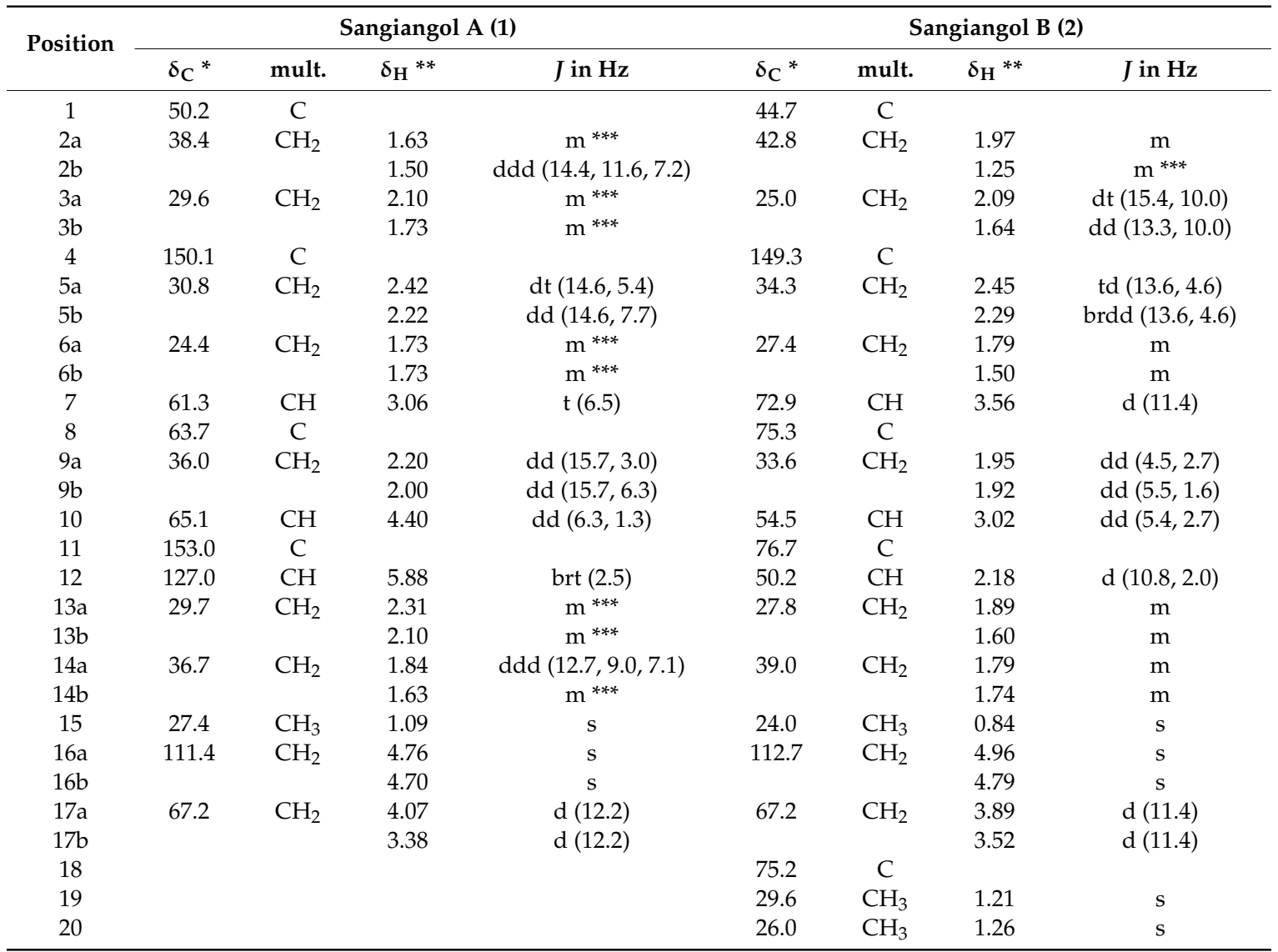

* Assigned by DEPT and 2D NMR (HSQC and HMBC) experiments. ${ }^{* *}$ Assigned by 2D NMR (COSY, HSQC, and $\mathrm{HMBC}$ ) experiments. ${ }^{* * *}$ Overlapping signals.

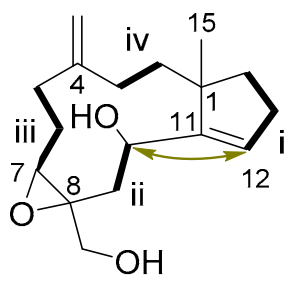

$1 \mathrm{a}$

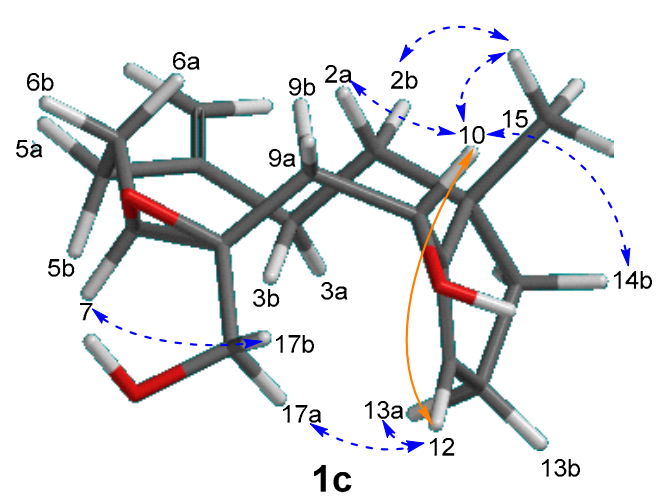

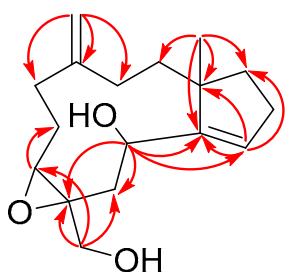

$1 b$

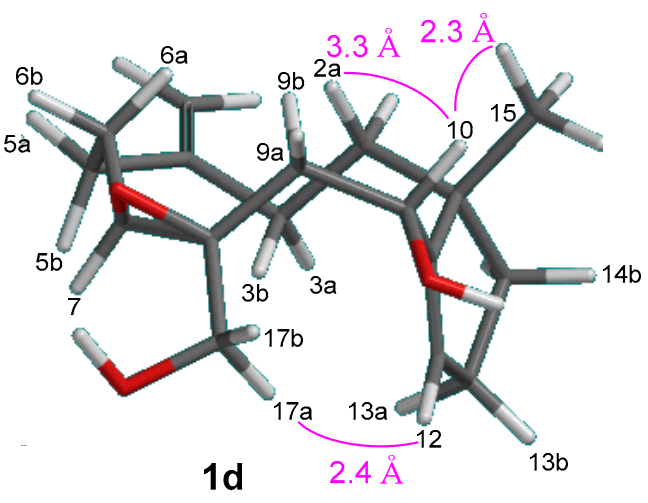

Figure 2. Cont. 

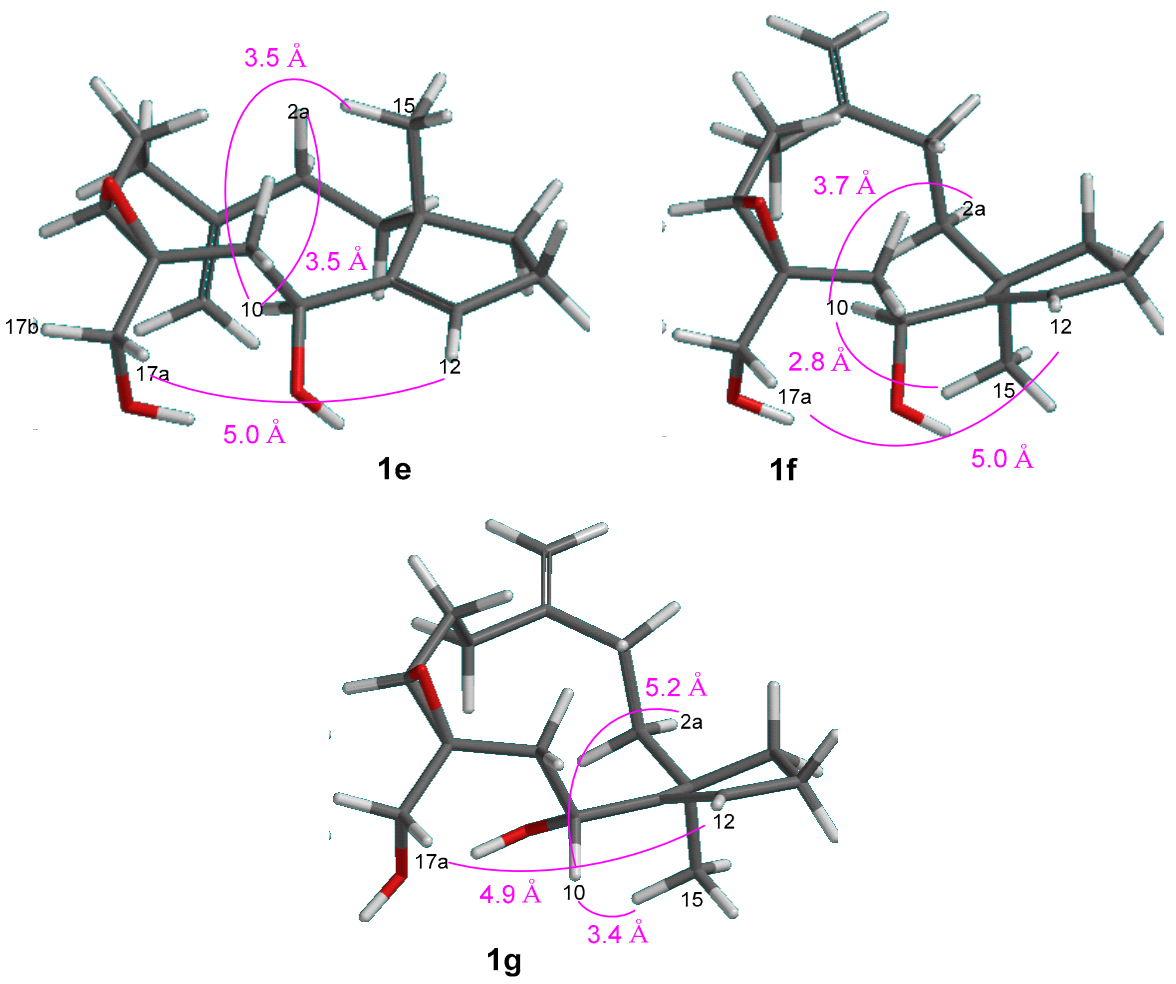

$-{ }^{1} \mathrm{H}-{ }^{1} \mathrm{H}$ COSY $\frown{ }^{1} \mathrm{H}-{ }^{13} \mathrm{C} \mathrm{HMBC} \rightleftharpoons$ Long range ${ }^{1} \mathrm{H}-{ }^{1} \mathrm{H}$ COSY
$\cdots$ NOE $\frown$ Distance in $\AA \curvearrowright$ Coupling Constant $\left({ }^{4} \mathrm{~J}_{\mathrm{H}-\mathrm{H}}\right)$

Figure 2. Key: COSY (1a), HMBC (1b), NOE (1c), correlations and a long-range coupling constant $\left({ }^{4} \mathrm{~J}_{\mathrm{H}-\mathrm{H}}\right)$, as well as the distance between atoms (1d), with a computer-generated model of $\mathbf{1}$ (energy minimized: $1 S^{*}, 7 S^{*}, 8 S^{*}, 10 R^{*}$ for $(\mathbf{1 c}) ; 1 S^{*}, 7 S^{*}, 8 S^{*}, 10 S^{*}$ for (1e); $1 R^{*}, 7 S^{*}, 8 S^{*}, 10 S^{*}$ for (1f); $1 R^{*}, 7 S^{*}$, $8 S^{*}, 10 R^{*}$ for $(\mathbf{1 g})$, obtained from calculations with molecular mechanics MMFF).

The relative stereochemistry of $\mathbf{1}$ was tentatively assigned as follows, based on positive NOEs (1c; Figure 2). By observing a strong NOE between H-7 and H-17b (1c; Figure 2), chirality at the epoxide was revealed to be $7 S^{*}, 8 S^{*}$, as in similar structural units [6,11]. Therefore, four possible stereoisomers-1c $\left(1 S^{*}, 7 S^{*}, 8 S^{*}, 10 R^{*}\right)$, 1e $\left(1 S^{*}, 7 S^{*}, 8 S^{*}, 10 S^{*}\right), \mathbf{1 f}\left(1 R^{*}, 7 S^{*}, 8 S^{*}, 10 S^{*}\right)$, and $\mathbf{1 g}\left(1 R^{*}\right.$, $7 S^{*}, 8 S^{*}, 10 R^{*}$ )—were further considered. Figure 2 shows the energy-minimized conformations of $1 \mathrm{c}$ and 1e-1g after molecular mechanics (MMFF) calculation. Of four possibilities, 1c was the most likely structure because a positive NOE was observed between $\mathrm{H}-17 \mathrm{a}$ and $\mathrm{H}-12$ within a reasonable distance (Figure 2), while other candidates were expected to have longer distances $(\sim 5 \AA)$. The angular methyl H-15 at $\delta_{\mathrm{H}} 1.09$ partially supported this conformation, showing NOEs for H-15/H-2b, 10 (Figure 2). The more downfield-shifted signal for the C-15 ( $\delta 1.09)$ of 1 compared to that $(\delta 0.85)$ of the stolonidiol of $4[6,11]$ may be due to the absence of the epoxide ring and the presence of an olefin at the ring junction.

Using HRESIMS and NMR, it was determined that sangiangol B (2), $[\alpha]_{\mathrm{D}}{ }^{27}+15$, has the molecular formula $\mathrm{C}_{20} \mathrm{H}_{34} \mathrm{O}_{5}$, with an additional oxygen and two hydrogen atoms compared to stolonidiol (4). Furthermore, four degrees of unsaturation in 2 indicated a similarity to clavinflol B $(5)[6,12]$, a chlorohydrin analog. A detailed 2D NMR (Figure 3) analysis of 2 revealed that the major differences between 2, 4, and 5 were the chemical shifts at C-7 $\left(\delta_{\mathrm{H}} 3.56, \mathrm{~d}(11.4) ; \delta_{\mathrm{C}} 72.9\right.$ for 2 and $\delta_{\mathrm{H}} 3.96, \mathrm{~d}(11.5)$; $\delta_{C} 67.2$ for 5$)[6,12]$ and at C-8 ( $\delta_{C} 75.3$ for 2 and 63.2 for 4) [6,11] (Figure 4$)$. With the NMR chemical shifts and high-resolution mass spectrometry (HRMS) data, compound 2 contained 1,2-diol at C-7 and C-8 for an epoxide in stolonidiol (4) or for a chlorohydrin in clavinflol B (5) [6,12]. Key HMBC correlations for H-7/C-8, 17; H-17/C-7, 8; H-9/C-7; H-10/C-8 further confirmed the position of the diol, establishing the planar structure. 
<smiles>C=C1CCC2OC(CCC(O)(CO)C(O)CC1)C(C)(C)CCC2C(C)(C)O</smiles>

$2 a$

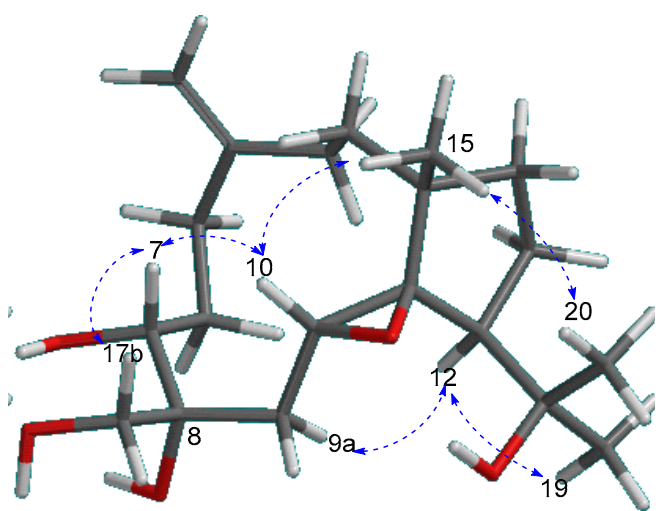

2c

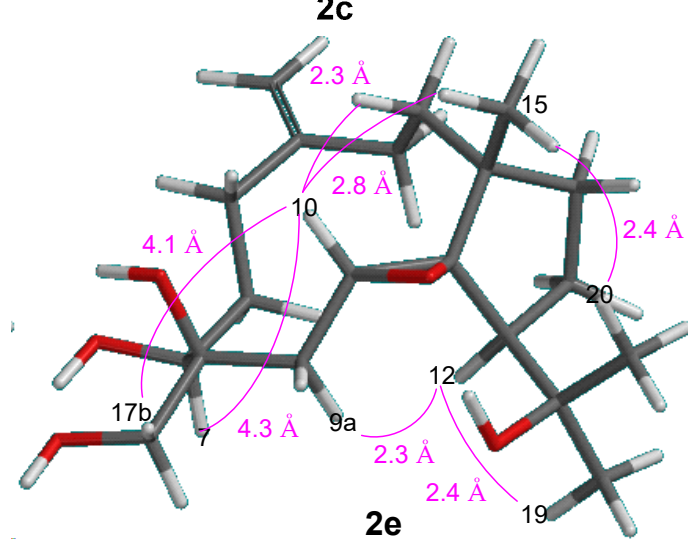

$2 e$

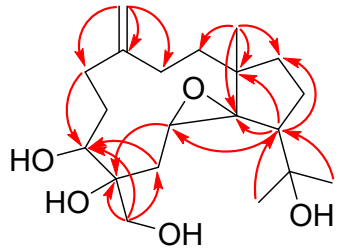

$2 \mathbf{b}$

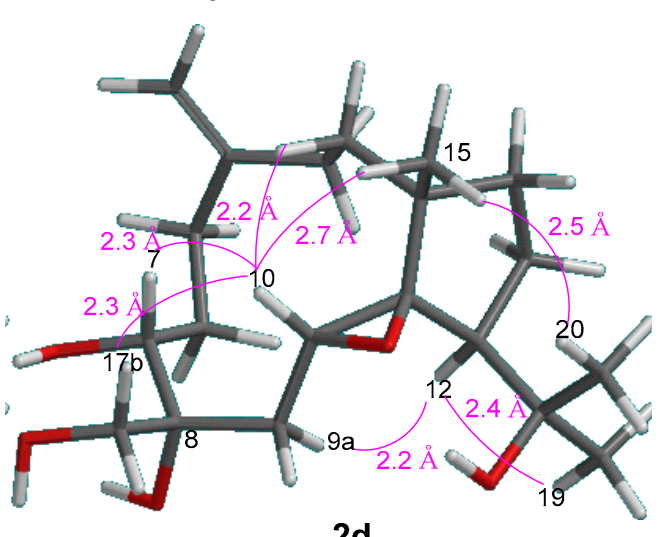

2d
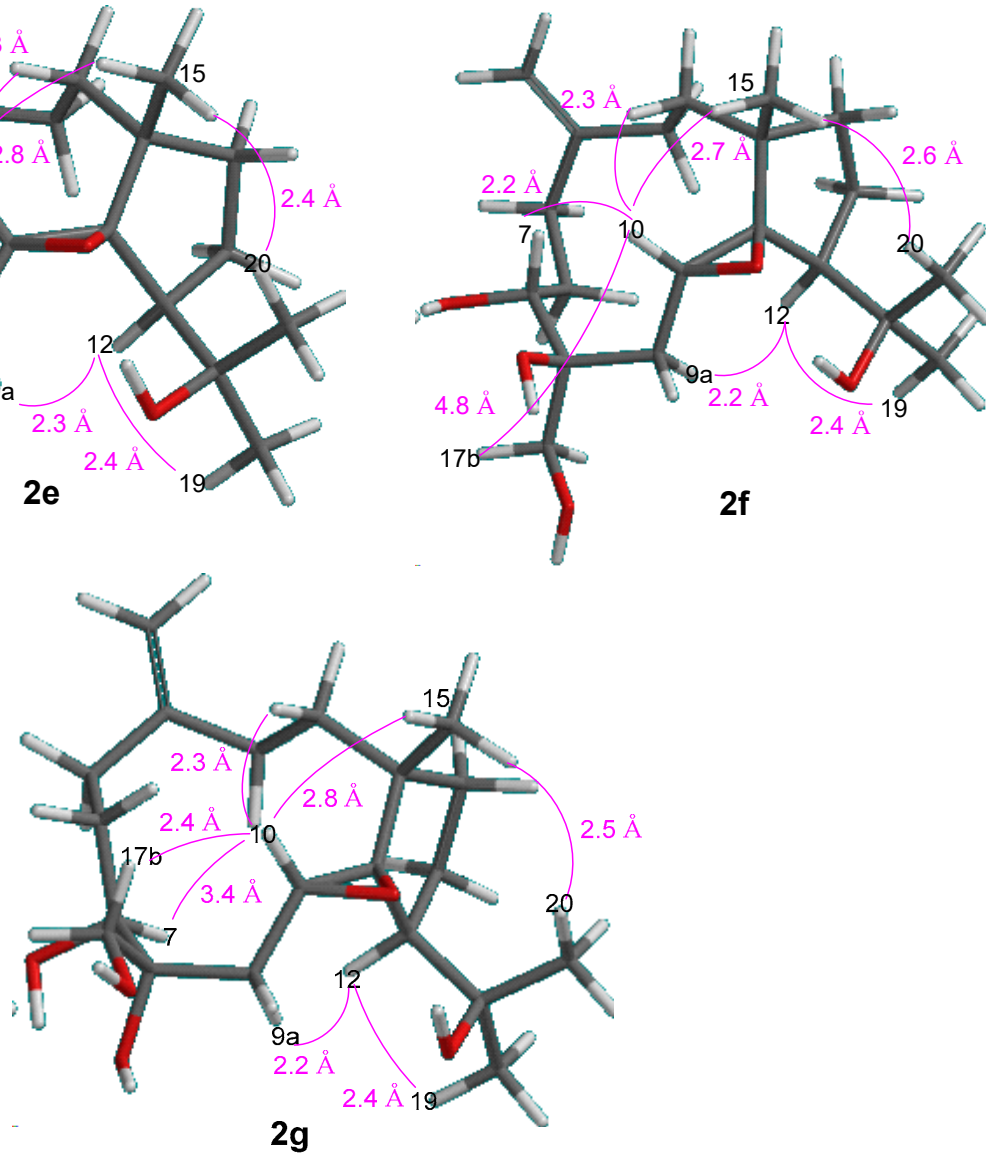

$2 \mathrm{~g}$

$-{ }^{1} \mathrm{H}-{ }^{1} \mathrm{H}$ COSY $\frown{ }^{1} \mathrm{H}^{13} \mathrm{C} H M B C \ldots$ NOE/NOESY $\frown$ Distance in $\AA$

Figure 3. Key: COSY (2a), $\operatorname{HMBC}(\mathbf{2 b}), \operatorname{NOE}(\mathbf{2 c})$, correlations and distance between atoms (2d) with a computer-generated model of 2 (energy-minimized $1 S, 7 R, 8 R, 10 R, 11 R, 12 S$ for $(2 \mathrm{c}) ; 1 S, 7 S, 8 S, 10 R$, $11 R, 12 S$ for (2e); $1 S, 7 R, 8 S, 10 R, 11 R, 12 S$ for $(\mathbf{2 f}) ; 1 S, 7 S, 8 R, 10 R, 11 R, 12 S$ for $(\mathbf{2 g})$, obtained from calculations with MMFF). 


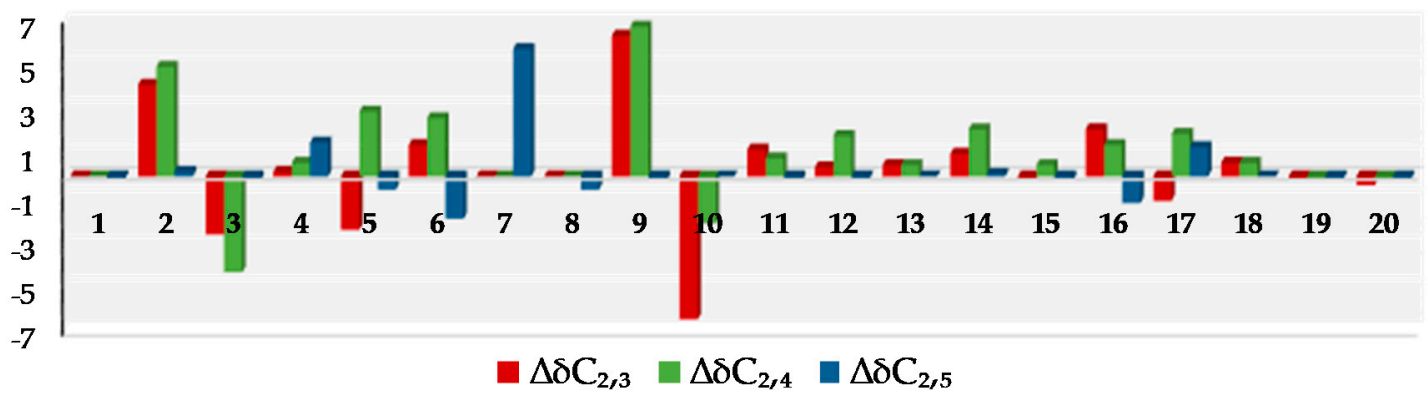

Figure 4. Comparative analysis of ${ }^{13} \mathrm{C}$ chemical shifts between 2 and $3,4,5$.

Of the six stereocenters of sangiangol B (2), three can be confirmed as $1 S, 11 R$, and $12 S$ by comparing the ${ }^{13}$ C-NMR data for the cyclopentane moiety (C-1, C-11 14) with those of 3, 4, and 5 (Figure 4) $[6,11,12]$ and by observing the rotation value $[\alpha]_{D}-37.9$ of co-isolated stolonidiol (4) and the value $[\alpha]_{D}-31$ of that reported in 4 , the absolute stereochemistry of which was established by X-ray crystallography [11]. Chirality at C-10 was shown to have the same $R$ configuration as stolonidiol (4), based on a positive NOE between H-10 and H-15. Among the four possible structures-2d: $7 R, 8 R, \mathbf{2 e :} 7 S, 8 S, \mathbf{2 f}: 7 R, 8 S$, and $2 \mathrm{~g}$ : $7 S, 8 R$ - the distances for $\mathrm{H}-10 / \mathrm{H}-7$ and $\mathrm{H}-10 / \mathrm{H}-17 \mathrm{~b}$ with energy-minimized conformations were compared, as in Figure 3. Both $\mathbf{2 e}$ and $\mathbf{2} \mathbf{f}$ were eliminated due to the relatively long distances of $\mathrm{H}-10 / \mathrm{H}-17 \mathrm{~b}$. However, as two candidates, $2 \mathbf{d}$ and $\mathbf{2 g}$, accorded with the spectral data, the configuration at C-8 was then revealed, while only C-7 remained to be solved.

Furthermore, the biosynthesis of stolonidiol-related molecules can be proposed, as in Figure 5. Geranylgeranyl pyrophosphate (GGPP) is a well-known starting material for diterpenoids [13]. Sangiangol A (1) could be derived from stolonidiol (4) through a series of degradation and epoxide ring-opening reactions, while sangiangol B (2) could be derived from sangiangol C (3) through an epoxidation reaction. Moreover, sangiangol C (3) could be the precursor of stolonidiol (4). Unfortunately, attempts to prepare $\alpha$-methoxy- $\alpha$-trifluoromethylphenylacetic acid (MTPA) esters for the determination of the absolute configurations of both molecules failed because of their instability and the small quantities of these compounds available.
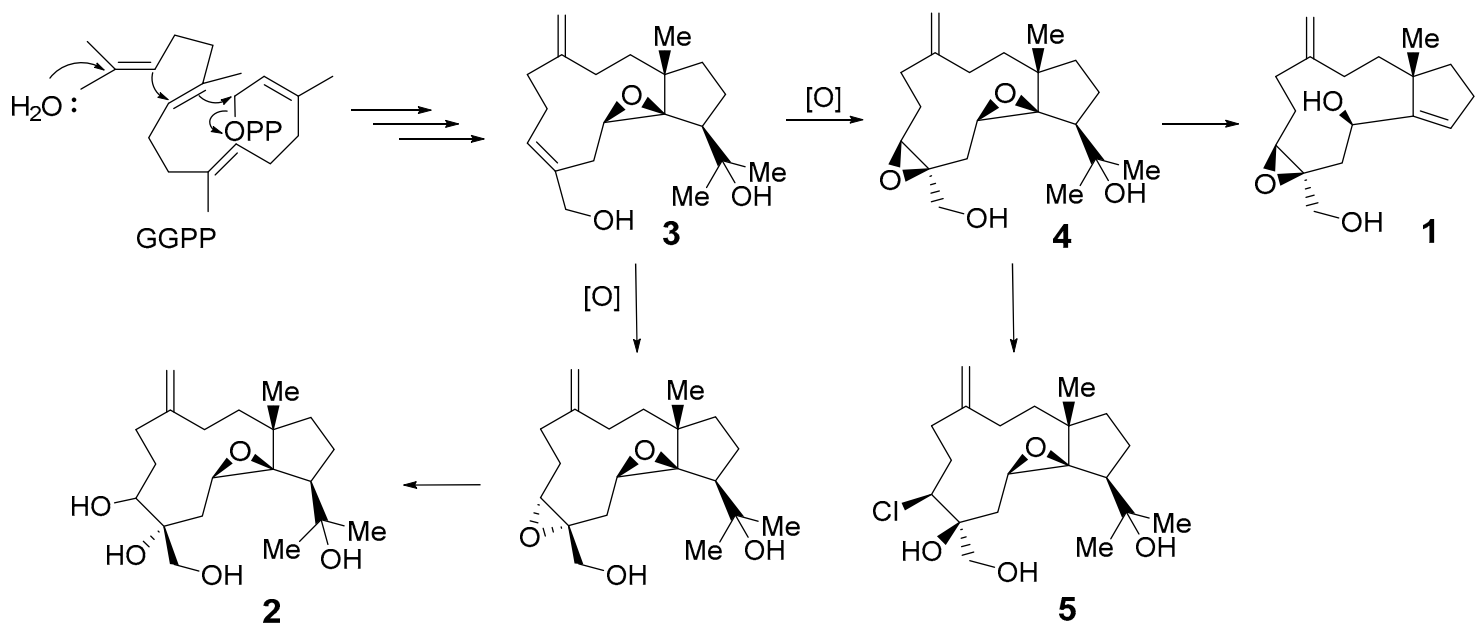

Figure 5. A possible biosynthetic pathway for sangiangols A (1) and B (2).

All isolated compounds (1-8) were evaluated for cytotoxicity against NBT-T2 rat bladder epithelial cells (Table 2). New entities 1 and 2 showed weak toxicity at 5 and $10 \mu \mathrm{g} / \mathrm{mL}$, respectively, while known molecules 3-8 showed moderate and weak toxicity at 10, 1, 0.5, 10, 1, and $10 \mu \mathrm{g} / \mathrm{mL}$, respectively. From the structure-activity relationship of stolonidiol derivatives, two epoxide rings or a chlorine atom are required for their cytotoxicity, as in 4 (stolonidiol) and 5 (clavinflol B). 
Table 2. Cytotoxicity of compounds 1-8 against NBT-T2 rat bladder epithelial cells.

\begin{tabular}{cc}
\hline Compound & Concentration $(\mu \mathrm{g} / \mathrm{mL})$ \\
\hline 1 & 5 \\
2 & 10 \\
3 & 10 \\
4 & 1 \\
5 & 0.5 \\
6 & 10 \\
7 & 1 \\
8 & 10 \\
\hline
\end{tabular}

\section{Materials and Methods}

\subsection{General Methods}

The optical rotations were obtained with a JASCO P-1010 digital polarimeter. The ${ }^{1} \mathrm{H}$ and ${ }^{13} \mathrm{C}-\mathrm{NMR}$ spectra were recorded on a JEOL $\alpha 500$ FT NMR spectrometer. The chemical shifts were expressed in $\delta$ (ppm) and the coupling constants $(J)$ in Hz. The electrospray ionization mass spectrometry (ESIMS) data were obtained on a PE QSTAR mass spectrometer and the infrared (IR) spectra were recorded on a DR 8020 Shimadzu spectrophotometer. The HPLC was performed on a Hitachi L-6000 pump equipped with a Shodex RI-101 monitor and a Hitachi L-4000 UV detector, using a Cosmosil 5C ${ }_{18}$ AR-II $(5 \mu \mathrm{m})$ or a Mightysil RP-18 $(5 \mu \mathrm{m})$ column. Merck silica gel $60(0.063-0.20 \mathrm{~mm})$ was used for column chromatography. The analytical thin layer chromatography (TLC) was performed on commercial silica gel $60 \mathrm{~F}_{254}$ visualized with vanillin-EtOH-1\% $\mathrm{H}_{2} \mathrm{SO}_{4}$. All solvents used were reagent grade.

\subsection{Animal Material}

A marine soft coral (AA-C31) was collected from Krakatau Island, Banten, Indonesia at 10-15 m depth by hand, while scuba diving. It was then stored in EtOH. The specimen was identified as Anthelia sp. by one of us (J.T.).

\subsection{Extraction and Isolation}

The fresh soft coral specimen (wet weight, $121 \mathrm{~g}$ ) stored in $\mathrm{EtOH}$ was extracted four times using $\mathrm{Me}_{2} \mathrm{CO}(4 \times 150 \mathrm{~mL})$. The four solutions were pooled and concentrated under vacuum, and the resulting residue was partitioned between EtOAc and $\mathrm{H}_{2} \mathrm{O}$ to obtain a cytotoxic lipophilic extract (1.57 $\mathrm{g}$, NBT-T2 $1 \mu \mathrm{g} / \mathrm{mL}$ ). The whole extract was separated on a Si gel 60 column by eluting stepwise with hexane-EtOAc-MeOH to afford 19 fractions. The second fraction (9.7 $\mathrm{mg}$ ) was further separated using normal phase silica HPLC (hexane 100\%) to give cembrane A (6) [13] (2.3 mg). The eighth fraction was purified on reversed phase HPLC to give sangiangol C (3) [14] (1.0 mg). The ninth fraction was repeatedly separated by HPLC (first, reversed-phase $\mathrm{C}_{18}\left(\mathrm{RP}_{18}\right), \mathrm{MeOH}-\mathrm{H}_{2} \mathrm{O}, 5: 2$; second, Si 60, $\left.\mathrm{CH}_{2} \mathrm{Cl}_{2}-\mathrm{EtOAc}, 7: 3\right)$ to afford kericembrenolide $\mathrm{E}$ (7) [15] (2.7 mg), stolonidiol (4) [6,11] (3.5 mg), and clavinflol B (5) [6,12] (1.3 mg). The tenth fraction was subfractionated on $\mathrm{RP}_{18} \mathrm{HPLC}$ to give cembrenolide (8) [16] (1.7 mg), sangiangol A (1) (1.3 mg), and stolonidiol (4) (103.7 mg). Finally, the most polar fraction was repeatedly separated on reversed-phase HPLC (first, $\mathrm{RP}_{18}: \mathrm{MeOH}-\mathrm{H}_{2} \mathrm{O}$, 2:1 second, $\left.\mathrm{RP}_{18}, \mathrm{MeOH}-\mathrm{H}_{2} \mathrm{O}, 4: 5\right)$ to give sangiangol $\mathrm{B}(2)$ (1.4 mg).

\subsubsection{Sangiangol A (1)}

Colorless oil; $[\alpha]_{\mathrm{D}}{ }^{27}+20\left(c 0.09, \mathrm{CHCl}_{3}\right) ; \mathrm{IR}(\mathrm{KBr}) v_{\max } 3418,2965,1683,1645,1456,1378,1168$, $1064 \mathrm{~cm}^{-1} ;{ }^{1} \mathrm{H}$ and ${ }^{13} \mathrm{C}-\mathrm{NMR}$ (see Tables 1 and 2); HRESIMS $m / z 301.1658[\mathrm{M}+\mathrm{Na}]^{+}$(calculated (calcd) for $\left.\mathrm{C}_{17} \mathrm{H}_{26} \mathrm{O}_{3} \mathrm{Na} 301.1779\right)$. 


\subsubsection{Sangiangol B (2)}

Colorless oil; $[\alpha]_{\mathrm{D}}{ }^{27}+15\left(c 0.14, \mathrm{CHCl}_{3}\right) ; \mathrm{IR}(\mathrm{KBr}) v_{\max } 3418,2965,1645,1456,1378,1168$, $1064 \mathrm{~cm}^{-1} ;{ }^{1} \mathrm{H}$ and ${ }^{13} \mathrm{C}-\mathrm{NMR}$ (see Tables 1 and 2); HRESIMS $\mathrm{m} / \mathrm{z} 377.2230[\mathrm{M}+\mathrm{Na}]^{+}$(calcd for $\mathrm{C}_{20} \mathrm{H}_{34} \mathrm{O}_{5} \mathrm{Na}$ 377.2304).

\subsection{Cytotoxicity Assay}

NBT-T2 rat bladder epithelial cells (BRC-1370) purchased from RIKEN (Tsukuba, Ibaraki, Japan) were cultured under a standard protocol using Dulbecco's modified Eagle's medium (DMEM). The cells were seeded in $1 \mathrm{~mL}$ of modified Eagle's media supplemented with $10 \%$ heat-inactivated fetal bovine serum, streptomycin, amphotericin B, and glutamic acid. The cells were exposed to graded concentrations of the new and known compounds, as well as their fractions at $37^{\circ} \mathrm{C}$, for $72 \mathrm{~h}$ and observed under a microscope to observe the effects at 48 and $72 \mathrm{~h}$.

Author Contributions: Conceptualization, N.H., A.M. and J.T.; methodology, N.H., A.M. and J.T.; validation, N.H., A.M. and J.T.; investigation, N.H., A.M. and J.T.; data curation, N.H., A.M. and J.T.; writing-original draft preparation, N.H., A.M. and J.T.; writing-review and editing, N.H., A.M. and J.T. All authors have read and agreed to the published version of the manuscript.

Funding: This research was partially funded by the Ministry of Research and Technology-National Research and Innovation (RISTEK-BRIN) of the Republic of Indonesia grant number (1769/IT3.11/PN/2018, 4175/IT3.L1/PN/2019, 4014/IT3.L1/PN/2020) and Ministry of Education, Culture, Sports, Science and Technology (MEXT) of Japan.

Acknowledgments: We thank the Ministry of Research and Technology-National Research and Innovation (RISTEK-BRIN) of the Republic of Indonesia for its support of N.H. through its excellent basic university research program (1769/IT3.11/PN/2018, 4175/IT3.L1/PN/2019, 4014/IT3.L1/PN/2020). We also thank Masaki Kita of Nagoya University for performing a database search.

Conflicts of Interest: The authors declare no conflict of interest.

\section{References}

1. Caroll, A.R.; Copp, B.R.; Davis, R.A.; Keyzers, R.A.; Prinsep, M.R. Marine natural products. Nat. Prod. Rep. 2020, 37, 175-223. [CrossRef] [PubMed]

2. Hanif, N.; Murni, A.; Tanaka, C.; Tanaka, J. Marine natural products from Indonesian waters. Mar. Drugs 2019, 17, 364. [CrossRef] [PubMed]

3. Berrue, F.; Kerr, R.G. Diterpenes from gorgonian corals. Nat. Prod. Rep. 2009, 26, 681-710. [CrossRef] [PubMed]

4. Hanif, N.; Murni, A.; Yamauchi, M.; Higashi, M.; Tanaka, J. A new trinor-guaine sesquiterpene from and Indonesian soft coral Anthelia sp. Nat. Prod. Commun. 2015, 10, 1907-1910. [PubMed]

5. Coval, S.J.; Scheuer, P.J.; Matsumoto, G.K.; Clardy, J. Two new xenicin diterpenoid from the octocoral Anthelia edmonsoni. Tetrahedron 1984, 40, 3823-3828. [CrossRef]

6. Murni, A.; Hanif, N.; Tanaka, J. A new cytotoxic dolabellane from the Indonesian soft coral Anthelia sp. Indones. J. Chem. 2013, 13, 216-220. [CrossRef]

7. Green, D.; Carmely, S.; Benayahu, Y.; Kashman, Y. Antheliolide A \& B: Two new C24-acetoacetylated diterpenoids of the soft coral Anthelia glauca. Tetrahedron Lett. 1988, 29, 1605-1608.

8. Smith, A.B.; Carrol, P.J.; Kashman, Y.; Green, D. Revised structure of antheliolides A and B. Tetrahedron Lett. 1989, 30, 3363-3364. [CrossRef]

9. Sjsstrand, U.; Bohlin, L.; Fisher, L.; Colin, M.; Djerassi, C. Minor and trace sterol from marine invertebrate 28: Novel polyhydroxylated sterol from soft coral Anthelia glauca. Steroids 1981, 38, 347-354. [CrossRef]

10. Mason, J.W.; Schmid, C.L.; Bohn, L.M.; Roush, W.R. Stolonidiol: Synthesis, target identification, and mechanism for choline acetyltransferase activation. J. Am. Chem. Soc. 2017, 139, 5865-5869. [CrossRef] [PubMed]

11. Mori, K.; Iguchi, K.; Yamada, N.; Yamada, Y.; Inouye, Y. Stolonidiol, a new marine diterpenoid with a strong cytotoxic activity from the Japanese soft coral. Tetrahedron Lett. 1987, 28, 5673-5676. [CrossRef] 
12. Shen, Y.; Pan, Y.; Ko, C.; Kuo, Y.; Chen, C. New dolabellanes from the Taiwanese soft coral Clavularia inflate. J. Chin. Chem. Soc. 2003, 50, 471-476. [CrossRef]

13. Ireland, C.; Faulkner, D.J.; Finer, J.; Clardy, J. A novel diterpene from Dollabella californica. J. Am. Chem. Soc. 1976, 98, 4664-4665. [CrossRef] [PubMed]

14. Vanderah, D.J.; Rutledge, N.; Schmitz, F.J.; Ciereszko, L.S. Marine natural products: Cembrene-A and cembrene-C from a soft coral, Nephthea species. J. Org. Chem. 1978, 43, 1614-1616. [CrossRef]

15. Kobayashi, M.; Son, B.W.; Kyogoku, Y.; Kitagawa, I. Kericembrenolides A, B, C, D, and E, five new cytotoxic cembrenolides from the Okinawan soft coral Clavularia koellikeri. Chem. Pharm. Bull. 1986, 34, 2306-2309. [CrossRef] [PubMed]

16. Iwashima, M.; Matsumoto, Y.; Takahashi, H.; Iguchi, K. New marine cembrane-type diterpenoids from the Okinawan soft coral Clavularia koellikeri. J. Nat. Prod. 2000, 63, 1647-1652. [CrossRef] [PubMed]

Sample Availability: Sample Availability: Not available.

(C) 2020 by the authors. Licensee MDPI, Basel, Switzerland. This article is an open access article distributed under the terms and conditions of the Creative Commons Attribution (CC BY) license (http://creativecommons.org/licenses/by/4.0/). 